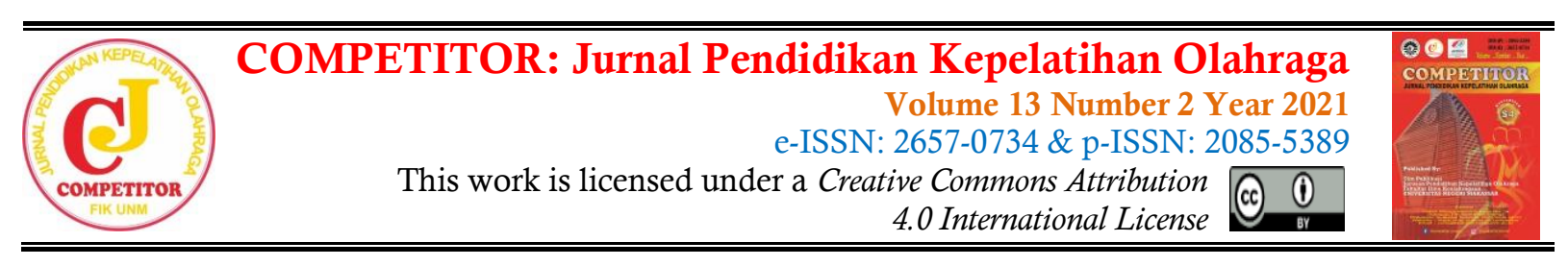

\title{
Exercise Activity Analysis and Paralympian Recovery Athletics During The Covid-19
}

\author{
Dyah Sukma Ramadhani ${ }^{1^{*}}$, Kunjung Ashadi ${ }^{2}$ \\ ${ }^{1,2}$ Faculty of Sports Science / State University of Surabaya / East Java / Indonesia \\ ${ }^{1,2}$ Street. Lidah Wetan, Surabaya, 60213, Indonesia \\ 1yah.17060474177@mhs.unesa.ac.id, ${ }^{2}$ kunjungashadi@unesa.ac.id
}

Received: April 14, 2021; Reviewed: May 6, 2021; Accepted: May 18, 2021;

Published: June 19, 2021

\begin{abstract}
The covid-19 pandemic period caused activities and the need for recovery paralysis to be disrupted, in other studies not much has analyzed training activities and athletic recovery during the covid-19 pandemic. Motion outside this research use non-experimental quantitative research methods and is written descriptively. The data was obtained by filling out the Google Form filled in by 13 Paralympian respondents. The data were analyzed by calculating the percentage. Thes results are Paralympian with sleep recovery $86 \%$ with the category always score and exercise activity reaches a percentage rate of $74,9 \%$, the frequency of exercise gets an average of $51,3 \%$ with the occasional category, the intensity of the exercise has an average number of 63,2\% with the frequent category, and the duration of exercise has an average rate of $53,8 \%$ with occasional category. The conclusions are that when the covid-19 pandemic hit, with the government's provisions that physical distancing does not limit the paralysis to carry out activities and carry out maximum recovery. The sleep to be the highest percentage of $86 \%$ with the always the data average reaches 73 which is the value of $81 \%-100 \%$, that the exercise activity or anaerobic and aerobic exercise has an average number of 74,9 with the frequent category, the intensity of light-moderate exercise has an average number the average was 63,2 with the frequent category and the exercise duration had 3045 minutes a day the mean score was 53,8 with the occasional category. Suggestion by staying consistent in doing exercise activities gradually.
\end{abstract}

Keywords: Covid-19; recovery; exercise activity.

\section{INTRODUCTION}

Covid-19 a new type of virus begins with "CO" meaning Corona, "VI" means from the virus and "D" for the actual name of the disease. In this case, a new type of Covid-19 is still a unity with (SevereAcute Respiratory Syndrome) SARS. Diseases spread through saliva or fluid from infected noses (World Health Organization, 2020). Expressed that covid-19 (coronavirus)is included in the dangerous virus, can be transmitted through the air without any gastrointestinal symptoms or breathing in line with cough, and sore throat (Yan et al, 2020). The impact of the coronavirus outbreak also called Covid-19 is sweeping around 
Exercise Activity Analysis And Paralympian Recovery Athletics During The Covid-19

Dyah Sukma Ramadhani ${ }^{*}$, Kunjung Ashadi ${ }^{2}$

dyah.17060474177@mhs.unesa.ac.id

the world, therefore to reduce this dangerous spread by cleaning hands, always wearing a mask when outdoors, spraying disinfectants at home and always obeying health protocols (Michael, A. L., Raymond, 2021).

The procedures implemented by the government provide action to the community for social restrictions on the activities of various units (physical distancing) as well as application procedures applicable to Paralympics to still be able to carry out training activities indirectly with trainers, which have been structured with virtual home exercises through video conferences according to the time set by their respective trainers, throughout the training process using smartphone video conferences to connect Paralympics with trainers (Ashadi et al., 2020).

Based on the inspection results of the World Health Organization (WHO), In general, professional athletes during the pandemic still have to do exercises with a process of exercise that has systematic repetition and provides increased weight training tiered, the repetition of paralympic training can be given a training program no different from nondisabled athletes but, it's just a way of adjustment and modification according to the condition of athletes (Ashadi, 2019). Exercise activities at home can provide a positive effect of strengthening immunity for health because it can weaken the virus with the resulting performance (Luzi, L., Radaelli, 2020) in this situation if it is not able to sort well will experience a decrease in health because the duration of exercise activities is less, recommended exercise activities ideally 150 minutes/week (Michael, A. L., Raymond, 2021).

A study mentions to maintain muscle mass during (physical distancing), It is better to do exercises by utilizing existing sports equipment at home as an example of strength training with weightlifting replaced with squat racks and chairs to maintain the frequency of such exercises (Latella et all 2020). As well as not eliminating recovery, recovery plays an important role in reducing fatigue and repairing damaged cells. The importance of recovery goes into the training program to minimize injuries suffered by Paralympians, but there is no denying there are injuries caused by training at home (Fahmi \& Kunjung, 2019).

But often Paralympians only do inconsistent exercise activities that can trigger the occurrence of a sedentary lifestyle often spend time staying at home (Ashadi et al., 2020). Most studies mention passive in moving causing changes in the body i.e. loss of muscle 
Exercise Activity Analysis And Paralympian Recovery Athletics During The Covid-19

Dyah Sukma Ramadhani ${ }^{*}$, Kunjung Ashadi ${ }^{2}$

dyah.17060474177@mhs.unesa.ac.id

mass, weight gain, the vulnerability of human health in cardiovascular, and will lead to decreased muscle capacity (Katrina et al, 2018).

This event becomes an obstacle to the ineffectiveness of coaches briefing athletes remotely. This problem occurred based on research through the filling of questionnaires at 13 Paralympic Puslatda athletics National Paralympic Committee Indonesia (NPCI) East Java. In the explanation above it is known that this study fact the majority of exercise activity and paralympic recovery is lacking, due to changes in physical condition when dangerous viruses spread.

This problem is limited in the literature of the research results showing the truth of analyzing exercise and recovery activities at the time of covid-19 into writing that needs to be discussed. The explanation is how important this research is to know how many changes in the current pandemic. This change occurred in the research subjects, namely exercise activities and paralympic recovery by analyzing the subjects of this study at the time of covid-19 as a matter of further discussion.

\section{METHOD}

In the method of research instruments put on quantitative non-experiment with descriptive research type. The target of this study was the Paralympics athletics centre for disabilities. With the number of respondents participating as many as 13 respondents are paralympic athletics. The participation of respondents with provisions on filling has criteria of status as a Paralympian Puslatda athletic disabilities sport and status as a member in disability organizations in NPCI East Java.

When retrieving data for research using data analysis techniques as follows: (1) calculation using mean for mean, (2) calculation using percentage, and (3) using standard deviation. By using a calculated questionnaire and has guaranteed to have passed the validation test process on the validation test question on the athlete's question with the amount of validation value declared valid because at r-count $(0.367)>r$-table is declared passed and the rehabilitation ability value is 0.604 using Microsoft Excel 2010 application and SPSS version 25. The data collection process is well prepared in google form, with an online system that fills respondents anytime and anywhere, researchers use a questionnaire containing 29 questions that must be filled by the Paralympics, filling the questionnaire does not use paper but through online using links sent through their respective WhatsApp groups. 
Exercise Activity Analysis And Paralympian Recovery Athletics During The Covid-19

Dyah Sukma Ramadhani ${ }^{1^{*}}$, Kunjung Ashadi ${ }^{2}$

dyah.17060474177@mhs.unesa.ac.id

In the duration of the data collection period for one month from February to March 2021, the collected data will be sorted according to questions and processed and will come out the results. Data that has been through the analysis process using percentages.

\section{RESULTS AND DISCUSSION}

After going through the process of disseminating questionnaires online questionnaire about paralympic training and recovery activities that are filled out questionnaires through a google form, it can be seen the following discussion, is the profile of the NPCI Paralympian East Java. The results of the research data obtained the following subject profiles. Of the 13 NPCI Paralympians in East Java, 11 were male and two were female. The result of the profile of the subjects is the age of the NPCI Paralympian East Java as follows.

Table 1.

Results Description of NPCI Paralympian Training Activities in East Java

\begin{tabular}{|c|c|c|c|c|c|}
\hline Variable & Subject & Mean \& SD & Min & Max & Percentage (\%) \\
\hline $\begin{array}{l}\text { Jogging min } 30 \text { minutes } 1 \text { week } 2 \\
\text { times. }\end{array}$ & Paralympics & $4,2 \pm 1,2$ & 1 & 5 & $82 \%$ frequent \\
\hline $\begin{array}{l}\text { Flexibility at least } 20 \text { seconds: neck } \\
\text { (neck), hands (arm swings), legs (leg } \\
\text { swings), dynamic stretching. }\end{array}$ & Paralympics & $4,2 \pm 0,8$ & 1 & 5 & $85 \%$ frequent \\
\hline $\begin{array}{l}\text { Push Up } 5 \text { sets } \times 10 \text { rep }=50 \text { Push } \\
\text { Ups } 1 \text { week } 2 \text { times. }\end{array}$ & Paralympics & $3,4 \pm 1,4$ & 1 & 5 & $65 \%$ frequent \\
\hline $\begin{array}{l}\text { Sit } U p 5 \text { sets } \mathrm{x} 10 \text { rep }=50 \text { Sit } U p s \\
1 \text { week } 2 \text { times. }\end{array}$ & Paralympics & $4,0 \pm 0,9$ & 2 & 5 & $80 \%$ frequent \\
\hline $\begin{array}{l}\text { Back Up } 5 \text { sets } \times 10 \text { rep }=50 \text { Sit } \\
\text { Ups } 1 \text { week } 2 \text { times. }\end{array}$ & Paralympics & $3,8 \pm 0,4$ & 3 & 4 & $75 \%$ frequent \\
\hline Lift thighs 4 x 100 m 1 week 2 times. & Paralympics & $4,0 \pm 1,2$ & 2 & 5 & $80 \%$ always \\
\hline Technique: $4 \mathrm{x}$ start block 1 flaying. & Paralympics & $3,5 \pm 1,1$ & 2 & 5 & $70 \%$ frequent \\
\hline $\begin{array}{l}\text { Sprint } 4 \text { x } 40 \text { m speed } 95-100 \% \\
1 \text { week } 2 \text { times. }\end{array}$ & Paralympics & $4,3 \pm 0,8$ & 2 & 5 & $86 \%$ frequent \\
\hline Bounding 4 x $100 \mathrm{~m} 1$ week $2 \times$. & Paralympics & $3,5 \pm 1,5$ & 1 & 5 & $66 \%$ frequent \\
\hline Jumps 100 times & Paralympics & $3,0 \pm 0,7$ & 2 & 4 & $60 \%$ sometimes \\
\hline
\end{tabular}

In table 1, there is a criterion that the exercise activities that stand out in $4 \times 40 \mathrm{~m}$ sprint exercises reach a percentage of $86 \%$ with frequent score descriptions. In addition to information that there is a difference before the covid-19 pandemic occurs and when the covid-19 pandemic occurs that sprint exercises increase the speed 4 times $40 \mathrm{~m}$ by using the start block reaches a percentage of $90 \%$ done 1 week 2 times every morning and evening, jogging $5 \mathrm{~km}$ reaches a percentage of $85 \%$. 
Exercise Activity Analysis And Paralympian Recovery Athletics During The Covid-19

Dyah Sukma Ramadhani ${ }^{1^{*}}$, Kunjung Ashadi ${ }^{2}$

dyah.17060474177@mhs.unesa.ac.id

Table 2.

Profile of Paralympic research subjects NPCI East Java.

\begin{tabular}{clc}
\hline Profile Of Research Subjects & Average & StandarDeviasi \\
\hline Age & 23 Years & 7,253 \\
\hline
\end{tabular}

The table above mentions that the age of the Paralympian with a minimum of 23 years has an average of 23 years and the standard Deviation with numbers 7,253.

Table 3.

Description of NPCI Paralympian Recovery Results East Java.

\begin{tabular}{llcccl}
\hline \multicolumn{1}{c}{ Variable } & Subject & Mean\&SD & Min & Max & \multicolumn{1}{c}{ Percentage (\%) } \\
\hline Colling Down & Paralympics & $4,0 \pm 1,2$ & 2 & 5 & $80 \%$ frequent \\
Cold Pack/Es & Paralympics & $3,3 \pm 1,5$ & 1 & 5 & $66 \%$ frequent \\
Sleep & Paralympics & $4,3 \pm 0,8$ & 3 & 5 & $86 \%$ always \\
Hydration & Paralympics & $3,0 \pm 0,7$ & 2 & 4 & $60 \%$ sometimes \\
\hline
\end{tabular}

In the table above can be seen that the Paralympics during the pandemic covid-19 do recovery or recovery sleep, reached the figure of $85 \%$ with the description of the score always. In addition to information that there is a difference in recovery at the time of the covid-19 pandemic and before the pandemic covid-19 paralympic recovery massage method by reaching the percentage of $90 \%$ with the category of score always and compression garment reached the percentage of $80 \%$ with the category of frequent scores.

Table 4.

Score Interachievement Description

\begin{tabular}{ccc}
\hline Score & Value & Description \\
\hline 1 & $0 \%-20 \%$ & Not at All \\
2 & $21 \%-40 \%$ & Not \\
3 & $41 \%-60 \%$ & Sometimes \\
4 & $61 \%-80 \%$ & Often \\
5 & $81 \%-100 \%$ & Always \\
\hline
\end{tabular}

The table is a score for the Likert scale to know the results of the assessment on the recovery and training activities of athletes and coaches in NPCI East Java according to (Riduwan, 2011).

Table 5.

Average Results of Npci Paralympic Training Activities in East Java.

\begin{tabular}{cc}
\hline Average & Category \\
\hline 74,9 & Often \\
\hline
\end{tabular}

Table 6.

Average Results of NPCI East Java's Npci Paralympic Frequency Training Activity

\begin{tabular}{ccc}
\hline Average & Standard Deviation & Category \\
\hline 51,3 & 3,74 & Sometimes \\
\hline
\end{tabular}


Exercise Activity Analysis And Paralympian Recovery Athletics During The Covid-19

Dyah Sukma Ramadhani ${ }^{1^{*}}$, Kunjung Ashadi ${ }^{2}$

dyah.17060474177@mhs.unesa.ac.id

Table 7.

Average Results of NPCI East Java Paralympic Intensity Training Activity.

\begin{tabular}{ccc} 
Average & Standard Deviation & Category \\
\hline 63,2 & 12,7 & Often \\
\hline
\end{tabular}

Table 8.

Average Results of NPCI East Java Paralympic Duration Exercise Activity.

\begin{tabular}{ccc}
\hline Average & Standard Deviation & Category \\
\hline 53,8 & 4,49 & Sometimes \\
\hline
\end{tabular}

Table 9.

Npci East Java Average Paralympic Recovery Results.

\section{Average}

73
Category

Sometimes

In the results of the study by using online questionnaires by filling through google form disseminated with WhatsApp group of each NPCI Paralympian East Java many questionnaires 29 points give the fact that at the time of this pandemic.

Average Results And Results of NPCI East Java Paralympic Training Activity Category. Based on the results of the questionnaire of paralympic training activities that have been filled as many as 13 respondents choose the answer and obtained the following categories that have gone through the counting process. Paralympic exercise mode (exercises used) anaerobic is at a value of $60 \%-80 \%$, in the calculation of paragliding shows that the average exercise activity obtained the figure of 74.9 which has the information that the NPCI Paralympian East Java often conducts training activities during the covid-19 pandemic. The frequency of exercises performed by Paralympians is carried out every week 2 times in each exercise an average of 51.3 which is a value of $41 \%-60 \%$, in calculations from the Paralympics shows that the average exercise activity that has a category sometimes. The intensity of exercises performed by the Paralympics was low to moderate on average 63.2 which was at a value of $61 \%-80 \%$, in calculations from the Paralympics showed that exercise activities obtained numbers that have a frequent category. The duration of the exercises performed by the Paralympics performed $30-40$ has an average of 53.8 which is at a value of $41 \%-60 \%$, in the calculation of the Paralympics shows that exercise activities have a category sometimes.

According to Setyaningrum, (2019) in line with research (Thompson, et al,2020). "It should be noted that by doing strenuous exercise activities during the covid-19 pandemic will trigger a decrease in the immune system and more ranges infected with the 
Exercise Activity Analysis And Paralympian Recovery Athletics During The Covid-19

Dyah Sukma Ramadhani ${ }^{*}$, Kunjung Ashadi ${ }^{2}$

dyah.17060474177@mhs.unesa.ac.id

dangerous covid-19 virus due to the impact on white blood cells, one of which is natural killer cells (NK), neutrophils and energy lymphocytes there is a decrease in the cytotoxic system".

According to Freemann (1989) written similarly in the book Sidik et al, (2019) "when doing training activities giving the training is very important by determining the intensity of exercise, guided by the type of intermediate intensity percentage of the maximum ability of 3-50, based on the pulse reaches 120-150 and moderate percentage of the maximum ability of 70-80 with a pulse of 150-170".

According to research by Mustofa et al, (2020) " on the frequency of exercise is set an average a for the activity of exercise 2 times a week, frequency is the most important thing to note. The intensity of exercise is a goal to perform the number of exercise activities performed 70-79\% maximizing movement and can minimize injuries. The duration of exercise activities within 30-45 minutes is enough for each exercise and (mode) or exercise used aerobic and anaerobic exercises can have good benefits with established procedures".

NPC East Java Paralympic Recovery Average Results And Results. The results of NPC paralytic recovery description of East Java showed the results of the recovery questionnaire conducted by the NPCI Paralympian East Java obtained the following categories that have gone through the process of calculating the number of $86 \%$ with the category always the data above has an average that the Paralympics reached the number 73 which is in the value of $81 \%-100 \%$, in the calculation of the Paralympics shows that the training activities obtained numbers that have the category always.

Revealing that sleep recovery is more commonly used, sleep helps the recovery process faster because it has certain benefits. The benefits of sleep are restoring physical repair of epithelial cells, maintaining balance metabolism and other benefits of sleep can relieve stress giving rest time especially the cerebral cortex that serves to remember, imagine, visualize a state (Lajoie et al, 2020).

According to Fawale's research. et al (2016) in line with the research of Reza et al, (2019) "Fatigue after completing exercise activities, sleep needs are very different adults show monophasic sleep patterns with a duration of 8 hours per night but the pattern can change to biphasic when the age of sleep cycle to meet the time of 8 hours per night and constraints felt, pre-sleep stage plays a role in this because pre-sleep is the preparatory phase of going to bed but not sleeping just lie down to relax the muscles after 
Exercise Activity Analysis And Paralympian Recovery Athletics During The Covid-19

Dyah Sukma Ramadhani ${ }^{*}$, Kunjung Ashadi ${ }^{2}$

dyah.17060474177@mhs.unesa.ac.id

self-mirelsasi pre-sleep muscles get a signal of drowsiness lasts 1 to 7 minutes in a state of relaxing by closing the eyes".

In contrast to the pre-sleep stage, the NREM stage (NonRapid Eye Movement)ranges from $75-80 \%$ of the total NREM deep sleep signal can also be called quiet sleep by initiating a decrease in the tonus muscle, peripheral blood vessels, at this stage of doing sleep without dreams but often having nightmares. The obstacle felt in the NREM stage is closing the eyes but the mind is still awake and woke up intentionally or unintentionally lasting 10 to 15 minutes.

REM (Rapid Eye Movement) signals a deep sleep that lasts 5 to 30 minutes when very sleepy does not last long even does not exist, the form of REM sleep accompanied by dreams that arise in the form of muscle activity of the body diving rem brain sleep provides its energy but the limbs are temporarily paralyzed. The separate function of REM sleep can smooth blood flow to the brain, increase activity and oxygen consumption of epinephrine(Reza et al., 2019).

There are some shortcomings of this study limitation of the number of not in large quantities and the less extensive literature in this regard can be used as a guideline for better development and in a wider number in the future.

\section{CONCLUSIONS AND SUGGESTIONS}

Based on the research data above this conclusion that when the pandemic covid-19 hit with the provisions of the government physical distancing does not limit to paralympic activities and make a maximum recovery. The result of the calculation of sleep to be the highest is done with a percentage of $86 \%$ with the category always data above has an average that the Paralympics reached the number 73 which is at a value of $81 \%-100 \%$, in the calculation of Paralympians shows that the exercise activity obtained figures that have a category always.

Based on the research data above the activity of aerobic exercise mode or aerobic exercise anaerobic has an average figure of 74.9 with frequent categories, the frequency of exercises performed a week 2 times earned an average of 51.3 with the category sometimes, the intensity of light-moderate exercise has an average figure of 63.2 with the category of frequent and at the duration of exercise has 30-45 minutes a day the average number of 53.8 with the category sometimes. Advice by keeping consistent doing exercise activities gradually. 
Exercise Activity Analysis And Paralympian Recovery Athletics During The Covid-19

Dyah Sukma Ramadhani ${ }^{*}$, Kunjung Ashadi ${ }^{2}$

dyah.17060474177@mhs.unesa.ac.id

\section{REFERENCES}

Ashadi, K., Laily, M.A., Bayu, A. P. (2020). Pola Aktivitas Olahraga Sebelum dan Selama Masa Pandemi covid-19 Pada Mahasiswa Fakultas Olahraga dan Fakultas Non-olahraga. Penelitian Pembelajaran, 6. https://doi.org/https://doi.org/10.29407/js_unpgri.v6i3.14937

Ashadi, K. (2019). Olahraga Disabilitas (K. Khusnul (ed.)). Uwais Inspirasi Indonesia.

Fahmi, H., Kunjung, A. (2019). Perbandingan Sports Massage dan Hydrotherapy Cold Water Terhadap Physiological. Juara: Jurnal Olahraga, Vol 4 No.2. https://doi.org/https://doi.org/10.33222/juara.v4i2.566

Fawale. M.B., Olanrewaju, I., Ishaq, I., Adekunle, F.M., Morenikeji, A.K., Michael, A.O., Tewogbade, A. A. (2016). Risk of obstructive sleep apnea, excessive daytime sleepiness and depressive symptoms in a Nigerian elderly population. Sleep Science, 9, 106-111. https://doi.org/10.1016/j.slsci.2016.05.005

Freemann, W. H. (1989). Peak When It Count. Pelatihan Pelatih Olahraga Disabilitas Tingkat Provinsi Jawa Timur Menuju Pekan Paralimpik Provinsi Jawa Timur I Tahun 2021 \& Pekan Paralimpik Nasional XVI Tahun 2021, Kota Mojokerto, 12-16 November.

Katrina L. P., Richard, P., Troiano., Rachel M Ballard., Susan. A. C., Janet E .F., Deborah, A. G., Stephanie, M .G., Richard, D. O. (2018). The Physical Activity Guideline For American. Journal Jama, 320 (19), 2020-2028. https://doi.org/https://doi.org/10.100/jama.2018.14854

Lajoie, A.C., Anne. L.L., Limoff, J.R. Marta, K. (2020). Obstructive Sleep Apnea in Neurodegenerative Disorders: Current Evidence in Support of Benefit from Sleep Apnea Treatment. Journal of Clinical Medicine, 9, 297. https://doi.org/10.3390/jcm9020297

Latella, C., G. Gregory, H. (2020). Global Challenges of Being a Strength Athlete during a Pandemic: Impact and Sports-Specific Training Consideration and $\begin{array}{lllll}\text { Recommendations. } & \text { Journal } & \text { Sports, } & 8, & 100 .\end{array}$ https://doi.org/https://doi.org/10.3390/sports8070100

Luzi, L., Radaelli, M. G. (2020). Influenza and obesity: its odd relationship and the lessons for COVID-19 pandemic. Acta Diabetologia, 57, 759-764. https://doi.org/https://doi.org/10.1007/s00592-020-01522-8

Michael, A. L., Raymond, P. (2021). Sports activities during any pandemic lockdown. Irish Journal of Medical Science, 190, 447-451. https://doi.org/https://doi.org/10.1007/s11845-020-02300-9

Mustofa, A., Hendri, I., Heru, S.L., Ridwan, M. (2020). Aktivitas Latihan Mahasiswa Prodi. Pendidikan Kepelatihan Olahraga FIK UNP. Jurnal Patriot, 2, 3. https://doi.org/https://doi.org/10.24036/patriot.v2i3.659 
Reza, R.R., Khairunnisa, B., Nisa, K., Arief, B. (2019). Fungsi Tidur dalam Manajemen Kesehatan. Majority, 8, 2.

Riduwan. (2011). Skala Pengukuran Variabel-Variabel Penelitian. Alfabeta.

Setyaningrum, D. A. . (2019). Cidera Olahraga serta penyakit terkait olahraga. Biomedika Dan Kesehatan, 2(1), 39-44. https://doi.org/10.18051/JBiomedKes.2019. v2.39-44

Sidik, D.Z., Paulus, L.P., Luky, A. (2019). Pelatihan Kondisi Fisik (Nita (ed.)). PT Remaja Rosdakarya.

Thompson, W. R., Sallis, R., Joy, E., Jaworski, C. A., Stuhr, R. M., Trilk, J. L. (2020). Exercise is Medicine. Journal of Lifestyle Medicine, Volume 14. https://doi.org/10.1177/1559827620912192

World Health Organization. (2020). CoronaVirus. https://www.who.int/healthtopics/coronavirus\#tab=tab_1

Yan. B., Lingsheng., Y. Tao., Wei. F.T., Dong-Y. J., Lijuan. C., M. W. (2020). Presumed Asymptomatic Carrier Transmission of Covid-19. Journal Jama, 323 (14), 1406-1407. https://doi.org/https://doi.org/10.1001/jama.2020.2565 